\title{
Canaries in the coal mine
}

\author{
Maeve Barry
}

Affiliations: EU Affairs Dept, European Respiratory Society, Brussels, Belgium.

Correspondence: M. Barry, EU Affairs Dept, European Respiratory Society, 49-51 Rue de Treves, 1040, Brussels, Belgium. E-mail: maeve.barrydersnet.org

0

@ERSpublications

Advocacy and policies are needed to reverse the drastic impact of air pollution on respiratory health http://ow.ly/p382I

Up until 30 years ago, coalminers relied on canaries as warning systems against harmful gases and pollutants underground. The miners listened for birdsong and if the birds fell silent, then they knew there was danger to their health and to take action. Today we have much more sophisticated information and reporting on the quality of air. We know precisely the levels and composition of pollutants in the air that are responsible for almost 500,000 deaths annually [1]. The problem is however, that nobody appears to be listening.

The air we breathe reduces our life expectancy by on average 8.6 months in Europe (fig. 1) [2]. Fine particle pollution (particles with a $50 \%$ cut-off aerodynamic diameter of $2.5 \mu \mathrm{m}$ ) is estimated to account for some 5 million lost years of life in the European Economic Area (www.efta.int/eea) countries every year [3]. Exposure to ground-level ozone concentrations above critical health levels is associated with more than 20000 premature deaths in the European Union (EU) annually [4]. Yet, 17 EU Member States are being taken to court by the European Commission for failing to meet air quality standards [5].

There is an awareness of the drastic health implications of air pollution. The European Respiratory Society (ERS) has been active in bringing this message to policymakers. There seems, however, to be a clear disconnect between the acknowledgement of the problem and a willingness to act to introduce measures to improve the situation. 2013 is the year of clean air, with revision of key European legislation, namely the National Emissions Ceiling Directive, expected for publication in autumn 2013. Instead of a legislative revision that would bring EU air quality in line with the (lower) maximum pollution levels recommended by the World Health Organization (WHO), the focus instead is likely to be on encouraging Member States to comply with existing (inadequate from a health perspective) legislation.

If we are to see an improvement in air quality, then we need to change the focus across all policy areas such as transport, energy and urban planning to prioritise the health benefits and savings of improved air quality over the potential costs of mitigation and infrastructure change. The current EU Thematic Strategy on Air Pollution estimates that implementing its objectives would lead to health savings of 42 billion euros per annum [6].

We need the adoption of sector legislation to cut emissions from all major sources, such as shipping, construction and agriculture. In other areas, we don't need to wait for new technologies or legislation. For example, retrofitting of public transport fleets can bring immediate reductions in the emissions of particulate matter and oxides of nitrogen. This was discussed at the Exhaust Retrofit Emission Control Alliance event which was held in the European Parliament on June 20, 2013 and hosted by Peter Liese (Member of the European Parliament). Where alternatives are available they must be promoted and chosen wherever possible. In addition, further measures such as low emission zones will help to protect those living

For editorial comments see page 1433.

Received: Aug 082013 | Accepted: Aug 082013

Conflict of interest: M. Barry is an employee of the European Respiratory Society.

Copyright (C)ER 2013 


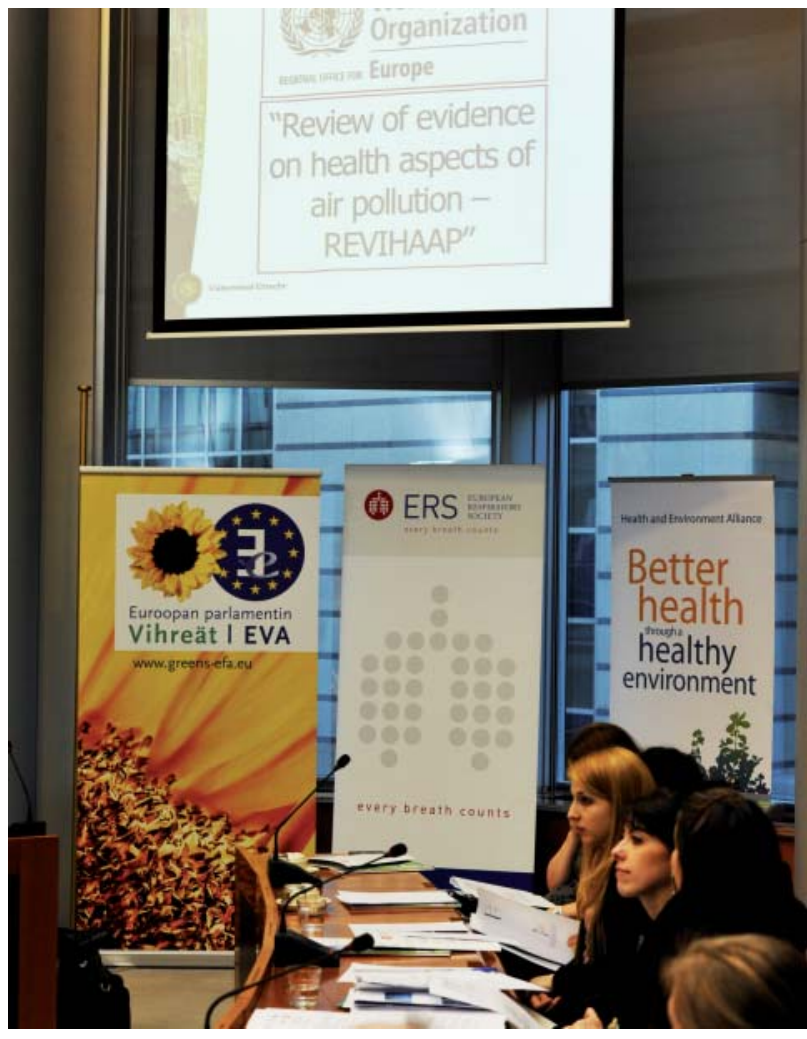

FIGURE 1 European Respiratory Society (ERS) Spotlight on Clean Air, hosted by S. Hassi (Member of the European Parliament) on March 19, 2013. The ERS "10 Principles for Clean Air", which featured in the European Respiratory Journal [2], were presented at an ERS event in the European Parliament. The Spotlight on Clean Air and Health event brought together Members of the European Parliament, European Union officials, Member States, local and regional representatives, patient groups and other stakeholders. The aim was to highlight the serious health implications of air pollution and provide the scientific and medical evidence to demonstrate as much.

in areas of busy traffic, which are usually those already suffering from health inequalities [7]. Local and regional governments, as well as municipal or city authorities have a key role to play in making sure that the transport, public services (such as schools and hospitals) and urban planning they provide take into account the need for cleaner air.

In taking these decisions, we must remind policymakers that excessive ozone $\left(\mathrm{O}_{3}\right)$ in the air triggers asthma and other lung diseases, reduces lung function and causes breathing problems [8]. Short-term exposure to nitrogen dioxide $\left(\mathrm{NO}_{2}\right)$ is associated with reduced lung function and airway responsiveness and increased reactivity to natural allergens. $\mathrm{NO}_{2}$ also contributes to the formation of particulate matter and $\mathrm{O}_{3}$. These pollutants result in increased deaths especially in sensitive population groups, such as the elderly, or those suffering from respiratory ailments. Indeed, recent studies show that in times of high air pollution, there is a marked increase in hospital admissions for respiratory and cardiovascular conditions [9].

For what concerns environment and health, the ERS is in a unique position to inform decision makers. ERS members can encourage local authorities to develop warning schemes for smog, pollutants and allergens that are known to adversely affect individuals with chronic lung disease, as well as support policy changes to reduce emissions contributing to climate change [10]. At the Society level, advocacy matters, it can and does make a difference; the ERS has a dedicated Environment and Health Committee which leads this advocacy work. In continuing to bring forward the message that air pollution is a serious threat, that it kills 500000 per year in Europe, the ERS and its members can help narrow the gap between awareness and action, just as canaries in the coalmine did.

\section{References}

1 European Topic Centre on Air and Climate Change. Assessment of the health impacts of exposure to PM2.5 at a European Level. ETC/ACC Technical Paper 2009/1. Bilthoven, ETC/ACC, 2009.

Brunekreef B, Annesi-Maesano I, Ayres JG, et al. Ten principles for clean air. Eur Respir J 2012; 39: 525-528.

3 European Environment Agency. Air Pollution - Key Fact 2. www.eea.europa.eu/soer/europe/air-pollution/keyfacts/air-pollution-fact-2 Date last accessed: August 7, 2013. Date last updated: September 30, 2011.

4 European Environment Agency. Air Pollution - Key Fact 4. www.eea.europa.eu/soer/europe/air-pollution/keyfacts/air-pollution-fact-4 Date last accessed: August 7, 2013. Date last updated: September 30, 2011.

5 European Commission. Environment: a fresh legal approach to improving air quality in Member States. http:// europa.eu/rapid/press-release_IP-13-47_en.htm Date last accessed: August 7, 2013. Date last updated: January 24, 2013. 
6 EUROPA. Thematic strategy on air pollution. http://europa.eu/legislation_summaries/environment/air_pollution/ 128159_en.htm Date last accessed: August 7, 2013. Date last updated: December 1, 2005.

7 Vidal J. North Circular air pollution worst in London, emissions figures show. The Guardian. June 24, 2013. World Health Organization. Air quality and health. www.who.int/mediacentre/factsheets/fs313/en/index.html Date last accessed: August 7, 2013. Date last updated: September 2011.

9 Åström C, Orru H, Rocklöv J, et al. Heat related respiratory hospital admissions in Europe in a changing climate: a health impact assessment. BMJ Open 2013; 3: e001842.

10 Ayres JG, Forsberg B, Annesi-Maesano I, et al. Climate change and respiratory disease: European Respiratory Society position statement. Eur Respir J 2009; 34: 295-302. 